\title{
V.P. Patyka
}

Zabolotny Institute of Microbiology and Virology,

National Academy of Science of Ukraine,

154 Acad. Zabolotny St., Kyiv, 03143, Ukraine

\section{PHYTOPATHOGENIC BACTERIA IN CONTEMPORARY AGRICULTURE}

The purpose. To study ecology, morphology, ultrastructure and biochemical characteristics of phytopathogenic bacteria; to determine bacterial diseases of plants and the patterns of their occurrence and development of the infectious process, to develop the mechanisms for plant disease control. Methods. Microbiological, physiological, biochemical, statistical. Results. Bacterial diseases of agricultural crops and related weeds and their causative agents in different cropping systems were described. Ecological niches of plant pathogenic bacteria were determined. Specialization of agents of bacterial diseases in plants was identified. Conclusions. It was established that a wide deterioration of crops and related weeds is caused by pathogenic bacteria of the following genera: Pseudomonas, Xanthomonas, Pectobacterium, Clavibacter, and Curtobacterium.

K e y w o r d s: phytopathogenic bacteria, bacterial diseases of plants, agricultural crops, weeds, ecological niches, lipopolysaccharides.

Plant pathogenic bacteria cause significant economic damage to agriculture. Pathogens are constantly surrounded by both cultural and wild plant species, affecting seeds and all plant organs during the growing season. They disrupt the normal flow of physiological processes in plants, causing necrosis and plant wilting, fruit rotting, leading to a partial or complete death of plants. In phytopathogenic bacteria affected plants, the number of fruits and berries gets reduced, the product quality is deteriorated and the yields decline. Often there is shortfall harvest.

In Ukraine, the efforts of the Department of Plant Pathogenic Bacteria are devoted to the study of bacterial diseases of many plant species, including cereals, pulses, vegetables, fruits, and forest crops, cotton, tobacco, rubber, Sudan grass, sugar beets and ginseng [6]. The Department of Plant Pathogenic Bacteria (until 1963 Plant Bacterioses Department) was one of the first in the newly created Zabolotny Institute of Microbiology and Immunology. The department was headed by H.O. Ruchko (until 1937), N.S. Novikova (1937 to 1943), K.H. Beltiukova (1943 to 1971), R.I. Hvozdiak (1971-2006), and by V.P. Patyka (since 2006) [6].

The department's staff has studied bacterial diseases of a significant number of plant species, including cotton, tobacco, rubber-bearing species, sugar beet, legumes (beans, soybean, pea, lupine, galega, etc.), grain crops (wheat, rye, oat, and rice), corn, rape, sorghum, Sudan grass, potato, carrot, tomato, pepper, cucumber, onion, fruits, forest plants, ginseng, etc. [6]. The results of these investigations formed the first volume of the monograph "Pathogenic Bacteria. Bacterial Diseases of Plants" issued in 2011 [7]. Somewhat later more reviews and problem articles were issued [15, 20, 21, 37]. Table 1 shows the crops studied and the causing agents of bacterial diseases identified.

(C) V.Ph. Patyka, 2016 
Bacterial diseases of Plants in Ukraine [21]

Table 1

\begin{tabular}{|c|c|}
\hline Crops & Isolated pathogens \\
\hline $\begin{array}{l}\text { Grain crops (wheat, rye, } \\
\text { barley, oat, millet, rice) }\end{array}$ & $\begin{array}{l}\text { Acidovorax avenae subsp. avenae (B. avenae), Bacillus } \\
\text { subtilis, Pantoea agglomerans (Erwinia herbicola), } \\
\text { Pectobacterium carotovorum (E. carotovora), Pseudomonas } \\
\text { syringae pv. atrofaciens, P. syringae pv. coronafaciens, } \\
\text { P. syringae pv. syringae (P. oryzicola), Pseudomonas } \\
\text { fluorescens, Xanthomonas oryzae pv. oryzae }\end{array}$ \\
\hline $\begin{array}{l}\text { Corn, sorghum, Sudan grass } \\
\text { sorghum }\end{array}$ & $\begin{array}{c}\text { P. carotovorum (E. carotovora), } P \text { syringae }(P . \text { holci), } \\
\text { P. syringae pv. syringae, } X \text {. vasicola pv. holcicola } \\
(X . \text { holcicola })\end{array}$ \\
\hline $\begin{array}{l}\text { Legumes (kidney bean, pea, } \\
\text { soybean, lupine, lentils, } \\
\text { alfalfa) }\end{array}$ & $\begin{array}{c}\text { Clavibacter insidiosum, Curtobacterium flaccumfaciens, } \\
\text { P. agglomerans (E. herbicola), P. carotovorum } \\
\text { (E. carotovora), P. marginalis (P. xanthochlora), } \\
\text { P. savastanoi pv. glycinea (P. syringae pv. glycinea), } \\
\text { P. savastanoi pv. phaseolicola, P. syringae pv. syringae } \\
\text { (P. vignae), P. syringae pv. pisi, P. syringae pv. tabaci, } \\
\text { P. syringae (P. lupini), X. axonopodis pv. glycines, } \\
\text { X. axonopodis pv. phaseoli } \\
\end{array}$ \\
\hline Potato & $\begin{array}{c}\text { B. subtilis, Clavibacter michiganensis ssp. sepedonicus } \\
\text { (B. sepedonicum), Pectobacterium atrosepticum } \\
\text { (E. phytophthora), P. carotovorum (B. carotovorum), } \\
\text { P. fluorescens, P. marginalis (P. xanthochlora), ralstonia-like } \\
\text { bacteria }\end{array}$ \\
\hline Carrot & P. carotovorum (E. carotovora), P. fluorescens \\
\hline Tomato & $\begin{array}{c}\text { C. michiganensis subsp. michiganensis, Erwinia } \\
\text { rhapontici, P. agglomerans (E. herbicola), P. carotovorum } \\
\text { (E. carotovora), P. corrugata*, P. fluorescens, P. marginalis } \\
\text { pv. marginalis (P. marginalis), P. syringae pv. tomato, } \\
\text { Ralstonia solanacearum, X. vesicatoria }\end{array}$ \\
\hline Sweet pepper & P. fluorescens, $P$. viridiflava \\
\hline $\begin{array}{l}\text { Cucumber, melon, } \\
\text { watermelon }\end{array}$ & $\begin{array}{c}\text { Erwinia toxica*, Pseudomonas burgeri*, P. carotovorum } \\
\text { (E. carotovora), P. syringae pv. lachrymans, Xanthomonas } \\
\text { cucurbitae }\end{array}$ \\
\hline Cabbage & $\begin{array}{c}\text { P. agglomerans (E. herbicola), P. carotovorum } \\
\text { (E. carotovora), P. syringae pv. maculicola (P. maculicola), } \\
\text { X. campestris pv. campestris }\end{array}$ \\
\hline Onion & $\begin{array}{l}\text { Burkholderia gladioli pv. alliicola (P. alliicola), } \\
\text { P. agglomerans (E. herbicola), P. carotovorum } \\
\text { (E. carotovora), Pseudomonas aeruginosa }\end{array}$ \\
\hline Cotton & $\begin{array}{l}\text { Xanthomonas citri subsp. malvacearum (B. malvacearum), } \\
\text { X. necrosis* }\end{array}$ \\
\hline Hemp & Pseudomonas cannabinae \\
\hline Rubber-bearing plants & P. agglomerans (E. herbicola), P. fluorescens \\
\hline Sugar beet & $\begin{array}{c}\text { Erwinia betae* (E. bussei), P. carotovorum (E. carotovora), } \\
\text { P. fluorescens, } P \text {. syringae ( } P \text {. wieringae), } P \text {. syringae pv. } \\
\text { aptata (P. aptata), Xanthomonas axonopodis (X. beticola), } \\
\text { X. axonopodis pv. vasculorum }\end{array}$ \\
\hline Rape & X. campestris, P. fluorescens \\
\hline Tobacco, Syrian tobacco & $\begin{array}{l}\text { P. carotovorum (B. carotovorum), P. syringae pv. tabaci } \\
\text { (P. tabaci) }\end{array}$ \\
\hline Vine & Agrobacterium tumefaciens \\
\hline
\end{tabular}




\begin{tabular}{|c|c|}
\hline Fruit trees & $\begin{array}{l}\text { A. tumefaciens, Bacterium nodoantrum } * \text {, E. amylovora, } \\
\text { Erwinia horticola*, P. carotovorum (E. carotovora), } \\
\text { P. fluorescens, P. syringae (P. cerasi), P. syringae pv. } \\
\text { morsprunorum (P. morsprunorum), X. arboricola pv. pruni } \\
\text { (X. pruni), rickettsia-like organisms }\end{array}$ \\
\hline Forest weed species & $\begin{array}{c}\text { Bacillus populi }{ }^{*} \text { B. subtilis, Clostridium butyricum, } \\
\text { E. horticola*, Erwinia nimipressuralis, Erwinia rhapontici, } \\
\text { P. syringae, P. syringae (P. cerasi), P. fluorescens }\end{array}$ \\
\hline Flower plants & $\begin{array}{l}\text { Bacillus sp., P. carotovorum (E. aroideae, E. carotovora), } \\
\text { P. fluorescens, P. fluoro-violaceus, Pseudomonas iridis* }\end{array}$ \\
\hline Ginseng & Pseudomonas cichorii \\
\hline Weeds & $\begin{array}{l}\text { P. agglomerans (E. herbicola), P. carotovorum subsp. } \\
\text { carotovorum (E. carotovora subsp. carotovora), } \\
\text { Pseudomonas sp., P. syringae, P. viridiflava }\end{array}$ \\
\hline Water plants & $\begin{array}{c}\text { Bacillus sp., Erwinia sp., P. carotovorum (E. carotovora), } \\
\text { Pseudomonas sp. }\end{array}$ \\
\hline
\end{tabular}

Note: In brackets, the names of pathogens are given as described by the author;

* - the name is not listed in Bergey's manual of systematic bacteriology.

Ukrainian collection of pathogenic bacteria of IMV NASU is unique and the most extensive in Eastern Europe. The collection numbers about 2,000 strains of 200 species and pathovars of pathogenic bacteria, and it is constantly updated with new strains from all around the world. This collection of pathogenic bacteria helps in solving various problems concerning taxonomy and ecology of phytopathogens, in studying their biological features and determining biological control methods against bacterioses [6, 7].

Serological methods are widely used for identification of pathogenic bacteria. According to its thermostable antigens, pathovars of $P$. syringae were classified into serogroups. For the first time, the chemical nature of the O-specific chains of the LPS core was identified in relation to serogroups, and their biological activity was determined $[6,13]$. In addition, the attribution of strains with a certain thermostable antigenic composition, to the conditions of habitation and plants feeding was first established [13]. In Ukraine, the affected wheat plants were infected with strains of the II, IV, V, and VI serogroups, (the IV prevailed). On oat plants, the strains of the I and the V serogroups were identified (the V prevailed); in Bulgaria, the II, IV, VI serogroups were identified on wheat. Strains of grain crops pathogens isolated as epiphytes dominate over other serological groups.

The main bacterial diseases of many crops have already been studied [6, 7]. However, an introduction of new varieties and cultivation technologies, an application of various farming practices and an excessive usage of pesticides, demand constant monitoring of the pathogens in nature. Therefore, since 2006 the department has conducted research on the role of pathogenic bacteria in contemporary farming systems. Intensification of agricultural production affects the properties of pathogenic bacteria and, therefore, the interaction within the soil-plants-phytopathogenic bacteria system.

Organic farming is just one example of a wide range of available management techniques that do not harm the environment. Organic farming practices are built upon certain specific requirements (standards) to the production process 
in order to support an optimal ecosystem state at the social, environmental and economic levels. Reuse of nutrients and enhancement of natural processes help to maintain soil fertility and to ensure a profitable production. The number of pests, as well as plant diseases, is controlled naturally as well as by using preventive biological and other modern scientifically grounded methods [1].

Thus, when studying the ecological role of pathogenic bacteria in the formation of balanced agrophytocoenoses, the department's staff monitored wheat bacterial diseases in relation to different doses of fertilizers applied and to the variety of preceding crops grown on the same fields. Pathogenic bacteria were identified and characterized in detail [14]. It was shown that the symptoms of the main wheat disease, namely basal bacteriosis, caused by Pseudomonas syringae pv. atrofaciens, varied being affected by the farming practices applied, the phase of plant development and the environmental factors. It was established that the increased amounts of nitrogen, phosphate and potassium fertilizers increase the probability of wheat infection with basal bacteriosis (P. syringae pv. atrofaciens) and black bacteriosis (Xanthomonas translucens) pathogens. The strains of $P$. syringae pv. atrofaciens, isolated from infected wheat plants were not highly selective: in the experiment, they affected weeds, such as thistles, field horsetail, and couch grass [30].

It was found that the affection of wheat and weeds with basal bacteriosis pathogen $P$. syringae pv. atrofaciens is lower under organic farming than under intensive farming practices.

Pseudomonas syringae are among the most common and harmful bacterial pathogens. This type includes 41 pathovars differing in their ability to affect certain host plant types. The problem of the systematic significance of such a taxon as a pathovar of a pathogenic bacterium, in particular, of the bacterial species $P$. syringae, has long been debated in scientific literature.

Many researchers indicate the close relationship between pathovars due to their biochemical, physiological and even genetic characteristics. In recent years, the amount of data has grown proving that genetic affinity within $P$. syringae species does not correspond to their classification into pathovars.

Thus, the classification of species into pathovars does not match the research data on the genomes of $P$. syringae species. Therefore, the classification into pathovars is artificial.

The DNA-DNA homology method is commonly used in investigating the diversity and genotypic classification. However, this method is very costly and time-consuming, and, therefore, cannot be used as an express-test for a large number of bacterial isolates, which is required in population studies [38].

A variety of methods is used to study genomes. Among them, there are DNA restriction analysis [41], the analysis of DNA repeat sequences resulting from amplification with REP-, ERIC-, and BOX- primers (rep-PCR) [2, 34, 35]. For example, Russian researchers [2] demonstrated a high degree of genetic variability in Pseudomonas strains obtained from infected tissues of grain crops with the symptoms of basal bacteriosis. According to the results of amplification with REP-, ERIC-, BOX- primers and ITS1 restriction analysis, all of the strains were divided into two genetic groups: "Syringae" and "Fluorescens".

The method of DNA amplification by the polymerase chain reaction (PCR) determined a new direction in modern methodology for establishing the 
genome selectivity. PCR allows detecting DNA polymorphism, which can be used to analyze inter/intraspecies variability.

One of the main difficulties, when using PCR to analyze the genomic variability, is the need to obtain information about nucleotide sequences in a genome or in variable regions of DNA for the purpose of primer selection.

To analyze the DNA polymorphism of basal bacteriosis pathogens we used RAPD PCR method.

RAPD is a random amplified polymorphic DNA that is a product of PCR with random primers $[39,40]$. Primers used for RAPD-PCR are relatively small (8-12 nucleotides), with random nucleotide sequences and $[\mathrm{G}+\mathrm{C}]$ content not less than $50 \%$ [41].

When using random primers, there is no need for determination of the nucleotide sequence of DNA segments under amplification, which greatly facilitates the analysis. Samples of electrophoretic distribution of amplified DNA (RAPDs) from different genetic sources may be subject to a comparative analysis, based on which the level of affinity is determined. Since RAPD-PCR method allows testing a large number of loci, it is promising for genetic studies of many objects.

RAPD-PCR analysis has been successfully used for populational genetic analysis of a wide range of microorganisms, and specifically for genetic analysis of Pseudomonas populations. This approach is widely used to study genetic polymorphism of plants. RAPD-PCR is a universal, easy, fast, and reproducible method.

The department's research found that belonging of all strains of $P$. syringae pv. atrofaciens to a determined serogroup doesn't depend on the year, geographic region and the host plant, from which the bacteria were isolated. The non-virulent strains and the strain isolated from oat were characterized by minor differences in comparison with the majority. The results of cluster analysis suggest that the $P$. syringae pv. atrofaciens strains under this study represent a genetically homogeneous group.

Our previous research found that pathogenic strains of $P$. syringae attributed to pathovars atrofaciens and coronafaciens did not differ in terms of their physiological and biochemical properties. The pathovar strains, isolated from infected and healthy plants, were identical in their qualitative fatty acid composition. Strains of different pathovars have similar protein profiles differing from those of other Pseudomonas species.

P. savastanoi pv. glycinea (angular leaf spot) and Xanthomonas axonopodis pv. glycines (bacterial leaf pustule) are the main causative agents of soybean bacterial diseases both in experimental and production sowings, The minor pathogens are represented by Pseudomonas syringae pv. tabaci and leaf rust pathogen Curtobacterium flaccumfaciens pv. flaccumfaciens, which was discovered in Ukraine for the first time (Fig. 1). Fatty acid composition of cellular lipids proved to be an effective chemotaxonomic technique for the identification of causative agents at both genus and species levels. The occurrence of soybean bacteriosis pathogens depends on the variety, cultivation technologies, quantitative pesticide load and the application of biological control methods $[7,8]$.

The researchers of our department found that weeds have a high competitive ability and endurance to adverse environmental conditions. They can be affected 
by bacterial pathogens and act as a cause of dangerous bacterial infections in agricultural crops $[5,30]$. In Ukraine, more than $85 \%$ of crops are located in the areas of high/medium weed infestation, which is one of the factors of the lowering efficiency of all measures aimed at increasing crop yield [3, 10, 11].

Satisfactory experimental results of some foreign researchers have confirmed the risk of bacterial infections being the initial cause of fungal diseases. Phytopathogenic bacteria act as pioneers affecting plants, which creates favorable conditions for further development of fungal infections $[12,33]$.

\section{Major and minor bacterial pathogens of soybean}

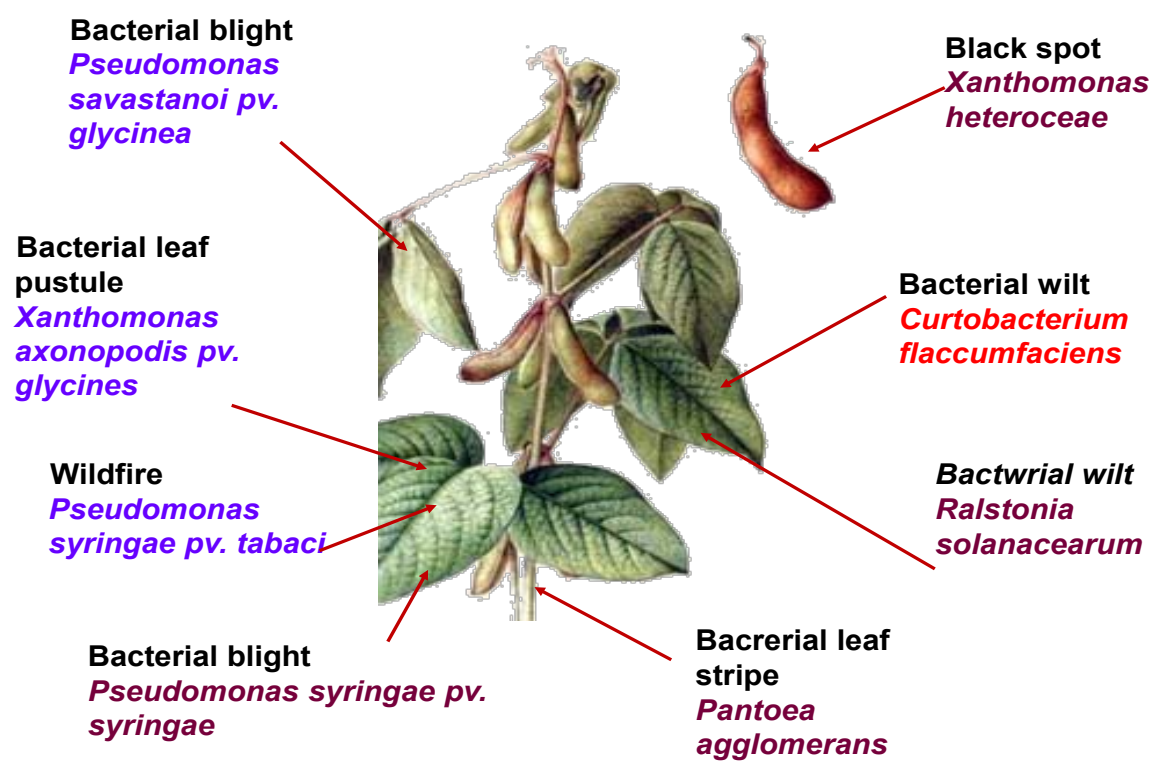

Fig. 1 Major and minor bacterial pathogens of soybean

It was established that the following weeds are the most common in all examined fields: the horsetail, field bindweed, couch grass, and clover. In the fields of the PE "Agroecology", besides the mentioned weeds, the predominant species included the creeping thistle and wild thistle, while in the experimental fields of the NSC of the Institute of Agriculture NAAS field violets prevailed. Monitoring of segetal vegetation of wheat agrophytocoenoses showed that the number of infected plants and the degree of damage to weeds was much lower in organic farming as compared to intensive farming [16, 27].

The area of pathogens occurrence is quite wide and covers 24 species of weeds. The most affected of them were horsetail, field bindweed, and field violet, from which the largest number of bacterial pathogens was isolated.

Out of 429 samples of weeds demonstrating the symptoms of bacterial destruction 689 isolates of bacteria were obtained; 194 of them were pathogenic to host plants. Identification of their virulent properties proved that most of them were highly aggressive in relation to horsetail and field bindweed, while less aggressive on couch grass, creeping thistle and wild thistle [16, 17, 22, 27].

One question may arise: are there phytopathogenic bacteria in the "Agroecology" fields? Yes, there are. But their number is small and 
environmentally safe. That is, they provide diversity. If there are certain pathogenic bacteria, there are also their antagonists, which fight against harmful bacteria and synthesize biologically active substances. Diversity provides for biosphere integrity. Diversity is deficient in agriculture. It's not as in nature, where interactions involve tens of thousands of species. In the fields, where a single permanent crop is grown, there is such a uniformity that no organisms are left to fight pests, so we had to carry out total chemicalization. But this is not the case in the PE "Agroecology" because they successfully exploit natural factors, namely microbiological ways of enrichment with nitrogen, returning organic matter back into the soil (green manure), which creates humus easier and faster. Owing to the microorganisms, straw decomposition in the soil occurs. [32]

In recent years, the department's attention was focused on rape, which is an important forage crop, a valuable predecessor of green manure capable of improving the phytosanitary condition of soils. [26]. Over the last ten years, it has strengthened its competitive position in the global market, significantly increased the gross yield of the seeds, its market has expanded. The area under this oil crop increases every year. However, today, rape is the third oil crop after soybean and sunflowers. Despite the relatively high profitability and the application in many fields of industry, analysis of rape sowings demonstrates that it is affected by agents of different etiology. Noteworthy is the fact, that rape diseases can cause a significant yield shortage and a significant reduction in the quality of its green mass and seeds. The affected plants have an increased content of carotene, dry matter, fiber, and ash while the content of vitamin C, protein, fat, and sugar is significantly reduced [23].

The analysis of changes in the general soil biogenicity, which is characterized by the development of major ecological and trophic groups of microorganisms, demonstrated that different groups respond differently to winter rape growing under different saturation and different rotation (Table 2).

Table 2

The number and the biomass of microorganisms in the meadow chernozem used for growing winter rape in rotation and permanently (average of 2010-2013) [23]

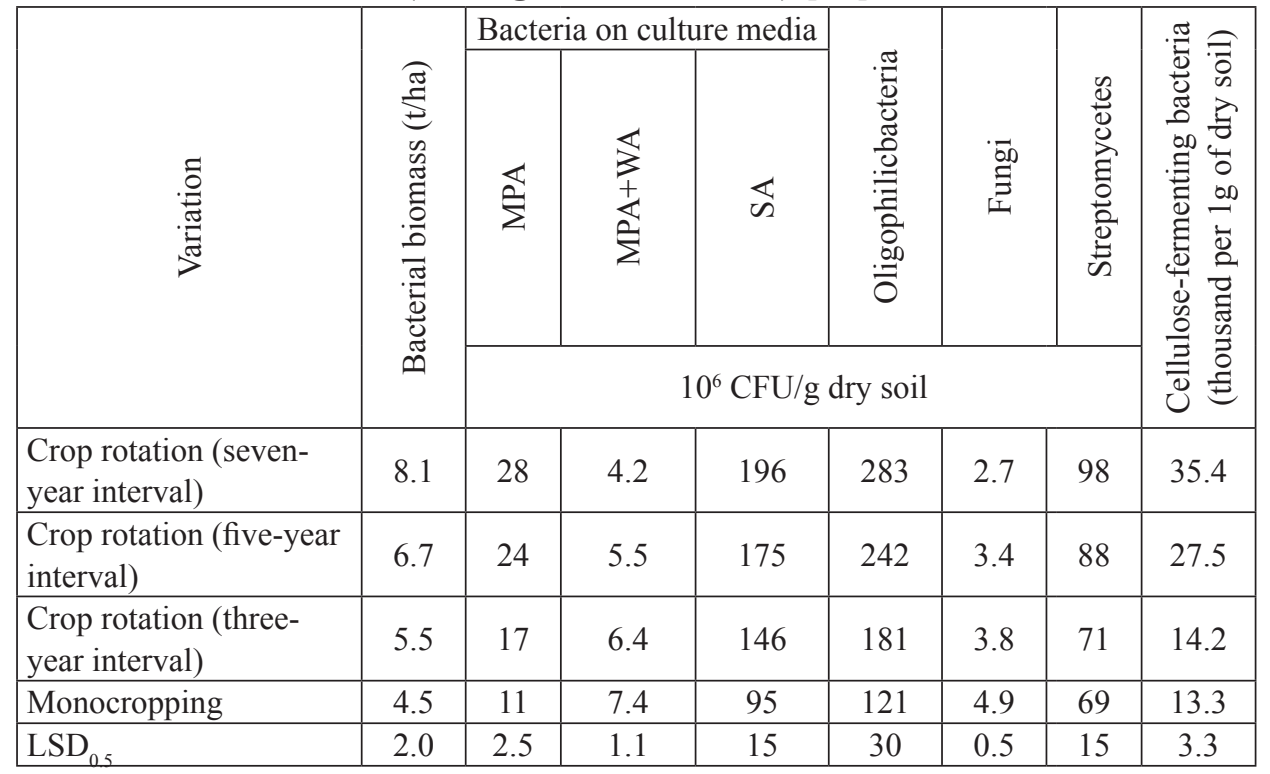


A less than 7-years interval in rape growing leads to the reduction of the number of bacteria in soil and their biomass. Thus, the biomass of bacteria in the rotation system (as compared to the monocropping approach) increased 1.8-fold, the number of oligonitrophilic bacteria involved in the transformation of the residual amounts of organic substances -2.3 -fold, streptomycetes -1.4 fold and more. The number of oligonitrophilic bacteria, in crop rotation soils, able to form colonies on agar was 2.1-fold greater than in monocultures. On the contrary, the content of fungi increased 1.8-fold when winter rape was grown in monoculture compared to crop rotation. Moreover, the study of fungi species in monoculture showed the dominance of Alternaria brassicicola, Alternaria brassicae, Alternaria tenuis, Phoma lingam, Peronospora brassicas, Fusarium oxysporum, Botrytis cinerea that are the pathogens causing alternariosis, phomosis, fusariosis, peronosporosis, botrytis, etc.

An increase in the number of bacilli and streptomycetes in soils of a rotation system indicates a deeper level of organic matter degradation. These groups of microorganisms metabolize compounds that are often unavailable to non-spore-forming bacteria. They can grow on substrates lacking available compounds $[23,36]$. Cellulose-fermenting microorganisms are also the indicators of mobilization processes in soil. According to our data (Table 2), the amount of these organisms was 2.6-fold higher under rotation conditions as compared to monocropping. Under rotation, the number of cellulosefermenting microorganisms in $1 \mathrm{~g}$ of dry soil was 35,400 , while in monoculture it constituted 13,000. Therefore, these findings confirm our research data on flax and tomatoes $[25,26]$, i.e. mobilization processes in soil occur more intensively in crop rotation systems rather than in monoculture.

Earlier $[9,18,36]$ we have shown that the population of pathogens causing bacterial diseases of rape is heterogeneous in nature: $78 \%$ of strains are highly aggressive and $11 \%$ are characterized by an average aggressiveness. It should be noted, that the most aggressive of all isolates was determined as a pathogen of mucous bacteriosis Pectobacterium carotovorum subsp. carotovorum and the least aggressive was found to represent a polyphage Pseudomonas fluorescens. All strains under study were quite aggressive to rape. In terms of the cultural, morphological and biochemical properties they are attributed to the main root bacteriosis pathogens Xanthomonas campestris pv. campestris, mucosal bacteriosis Pectobacterium carotovorum subsp. carotovorum and Pseudomonas fluorescens. Conditionally pathogenic bacteria (so-called opportunistic microorganisms) can become pathogenic for crops. These include $P$. agglomerans, P. fluorescens, B. subtilis and others that keep a contact with plants similar to saprophytes. Under certain conditions, they shift from saprophytes to parasites. A characteristic feature of them is the absence of plant (organ) selectivity. They cause diseases of cereals, legumes, vegetables, wood, floral and ornamental crops and weeds [7]. For the first time, in 2003, a massive affection of soybean stems with $P$. agglomerans was detected, which did not reduce the yield, but intensified the development of diseases caused by other phytopathogenic bacteria and micromycetes. The role of weather conditions on the expression of pathogenic properties of $P$. agglomerans and other pathogens was observed [7, 8, 21].

Despite the prospects of biologic preparation in Ukrainian agriculture, a preference is currently given to the pesticides of chemical origin to protect crops against pathogens. It is, therefore, advisable to use such pesticides, 
which in addition to antifungal action reveal antibiotic activity against bacterial diseases [25]. It was found that the formulations containing benomil, fludioxonil, penkonazol, difenokonazol, thiophanate-methyl do not have any antibacterial action against all strains under investigation, namely $P$. syringae pv. atrofaciens, $A$. tumefaciens, $P$. carotovorum, $X$. vesicatoria, $P$. syringae $\mathrm{pv}$. lachrymans. Only mancozeb and mancozeb in combination with metalaxyl demonstrated antibacterial action against the strains of grain bacteriosis $P$. syringae pv. Atrofaciens, A. tumefaciens, $X$. vesicatoria, and $P$. syringae pv. lachrymans. The formulations containing this active ingredient at the studied dose (recommended by the manufacturer) inhibit bacteria growth [21, 37].

The antagonistic activity of bacterial strains of Bacillus genus against pathogens of tomato bacteriosis was investigated. Six highly stable antagonists with a broad spectrum of action against pathogens of tomato bacteriosis, nontoxic, and able to stimulate tomato seedlings were determined. They may be promising for the creation of biopesticides for the protection of tomato plants against bacterial pathogens. It was revealed that Bacillus subtilis IMO-7023 and $B$. pumilus 3 are promising to protect tomatoes from $C$. michiganensis subsp. michiganensis. These strains of bacilli affect the development of the pathological process caused by the agent and reduce the disease symptoms [31].

In addition to their negative role, phytopathogenic bacteria may possess positive properties: they can be producers of biologically active substances. Thus, a pathogen of cabbage vascular bacteriosis - Xanthomonas campestris is also a producer of exopolysaccharide xampan. The possibility of wide use of exopolysaccharide xampan in many industries (textile and food), agriculture, and in secondary oil recovery was demonstrated [37]. Xampan was proved to have detoxification and radioprotective properties by activating protective antioxidant functions, which help to normalize the gastrointestinal tract microbiota and reveal antimutagenic activity. Therefore, xampan is recommended as a functional supplement to low-calorie diet and nutritional therapy [21]. Based on xampan and acrylamide a biological gel EPAA was developed. It was proved to be promising for use in woodwork, textile, microbiological industry and agriculture $[6,20,21]$. The use EPAA as a sticker for pesticides in agriculture allows for a $30 \%$ decrease in their application rate.

Thus, a large-scale affection of crops and accompanying weeds by bacterial pathogens of Pseudomonas, Xanthomonas, Pectobacterium, Clavibacter, and Curtobacterium genera was established.

Microorganisms, including phytopathogenic bacteria in agricultural soils, are known to determine the nutrient regime for plants, the incidence of diseases and the yield quality. The level of agricultural production is possible at the condition of sustenance balance of soil biological processes, which in turn are determined by microorganisms. Soil health depends on the ability of soil microorganisms to resist (or compete with) pathogens during the ontogeny of plants [4]. The scale degree, and the activity of soil microbiota, including phytopathogenic bacteria, depends on the applied farming practices. In all branches of agriculture, the control of the microorganisms content and their trophic flow provides a high rate of plant ontogenesis [4, 24, 28]. A key factor underlying the functional management of soil microbiome in oligotrophic systems is the formation of carbon nutrient flows (crop rotation, organic and mineral fertilizers, pesticides, etc.). 
The role, functions, and mechanisms that shape the microbial diversity in soils is still not yet fully understood. There is a suggestion that those soils that have the greatest diversity of microorganisms are resistant to human impact, including the development of pathogenic bacteria. Anthropogenic land use and management of agricultural production have been identified as the most important factors affecting biodiversity. Ecology of microbial interactions, that shape the environment and processes in the "soil-plant-pathogens" system, requires a comprehensive study. Today, this issue draws the department's research efforts.

\section{В.П. Патика}

Інститут мікробіології і вірусологї ім. Д.К. Заболотного НАН України, вул. Академіка Заболотного, 154, Київ, 03143, Україна

\section{ФІТОПАТОГЕННІ БАКТЕРІЇ В СУЧАСНОМУ СІЛЬСЬКОМУ ГОСПОДАРСТВІ}

Резюме

Мета. Вивчення екології, морфології, ультраструктури, біохімічних показників збудників бактеріальних хвороб рослин, закономірностей виникнення, розвитку інфекційного процесу та підбір засобів боротьби з хворобами, що вони спричиняють. Методи. Мікробіологічні, фізіологічні, біохімічні, статистичні. Результати. Описано бактеріальні хвороби сільськогосподарських культур, бур'янів, а також біологічні властивості їх агентів у різних системах землеробства. Встановлено екологічні ніші виживання рослин за дії фітопатогенних бактерій. Визначено спеціалізацію збудників бактеріальних хвороб на рослинах. Висновки. Встановлено розповсюдження та збільшення ураження посівів сільськогосподарських рослин і бур'янів збудниками бактеріальних хвороб, що належать до родів Pseudomonas, Xanthomonas, Pectobacterium, Clavibacter i Curtobacterium.

Ключові слова: фітопатогенні бактерії, бактеріальні хвороби сільськогосподарських культур і бур'янів, екологічні ніші, ліпополісахариди.

\section{В.Ф. Патыка}

Институт микробиологии и вирусологии им. Д.К. Заболотного НАН Украинь, ул. Академика Заболотного, 154, Киев, 03143, Украина

\section{ФИТОБАТОГЕННЫЕ БАКТЕРИИ В СОВРЕМЕННОМ СЕЛЬСКОМ ХОЗЯЙСТВЕ}

Резюме

Цель. Изучение экологии, морфологии, ультраструктуры, биохимических показателей возбудителей бактериальных болезней растений, закономерностей возникновения, развития инфекционного процесса и подбор средств борьбы с болезнями, которые они вызывают. Методы. Микробиологические, физиологические, биохимические, статистические. Результаты. Описаны бактериальные болезни сельскохозяйственных культур, сорняков, а также биологические свойства их агентов в различных системах земледелия. Установлены экологические ниши выживания растений при действии фитопатогенных бактерий. Определена специализация возбудителей бактериальных болезней на растениях. Выводы. Установлено распростра- 
нение и увеличение поражения посевов сельскохозяйственных растений и сорняков возбудителями бактериальных болезней, принадлежащих к родам Pseudomonas, Xanthomonas, Pectobacterium, Clavibacter и Curtobacterium.

Ключевые слова: фитопатогенные бактерии, бактериальные болезни сельскохозяйственных культур и сорняков, экологические ниши, липополисахариды.

1. Antonets SS, Pysarenko VM, Opara MM, Pysarenko PV, Chekrizov IO, Moskalenko $S L$, et al. [Organic farming: guidelines] Practical recomen. - Poltava: RVV PDAA, 2010. - 20 p. Ukrainian.

2. Bobrova VK, Milyutina IA, Troitskiy AV. [Genetic diversity of Pseudomonades associated with crops affected with basal bacteriosis] Microbiology. 2005; 74(4): 537-544. Russian.

3. Burda RI. [The concept of the modern science of weeds] The Agricultural and Ecological Journal. 2002; 1: 3-11. Ukrainian.

4. Gadzalo YaM, Patyka NV, Zarishnyak AS. [Agricultural biology of the plant rhizosphere: monograph] - K.: Agr. Nauka, 2015. Ukrainian

5. Gvozdyak RI, Yakovleva LM, Shcherbina TN, et al. Sornye rasteniya kak ekologicheskaya nisha fitopatogennykh bakteriy Zbirnik statey uchasnikiv Mizhnarodnoï naukovoï konferentsiï. "Pathogenic bacteria. Phytoncidology. Allelopathy." 2005. p. 55-59. Ukrainian.

6. Hvozdiak RI, Pasichnyk LA, Patyka VP. [The Pathogenic Bacteria Department: the past and the present] Microbiology Journal . 2008; 70(2-3): 48-54. Ukrainian.

7. Hvozdiak RI, Pasichnyk LA, Yakovleva LM, Moroz SM, Lytvynchuk OO, Zhytkevych $N V$, et al. Fitopatohenni bakterii. Bakterialni khvoroby roslyn: [monograph: v 3-kh t.]. T. 1.-K.: TOV «NVP «Interservis», 2011. Ukrainian.

8. Zhytkevych NV, Patyka VF. [Diseases of soya] Grain. -2010; 9: 56-60. Russian.

9. Zakharova OM, Melnychuk MD, Dankevych LA, Patyka VP. [Bacterial diseases of oilseed rape] Microbiology Journal. 2012; 74(6): 46-52. Ukrainian.

10. Ivashchenko OO. [Weeds in sowings: a big problem] Plant Quarantine and Protection. 2009; 9: 2-4. Ukrainian.

11. Ivashchenko OO. Herbolohiia - pohliad u maibutnie / OO Ivashchenko // Materialy 7-yi nauk.-teo-retych. konf. Ukr. nauk. tov. herbolohiv [«Roslyny-buriany: osoblyvosti biolohii ta ratsionalni systemy yikh kontroliuvannia v posivakh s.-h. kultur»] [Herbology: looking into the future. "Weeds: biological features and rational system of their control in agricultural crops"], (Kyiv, 5-6 berez. 2010 r.). K., Kolobih; 2010. P. 10. Ukrainian.

12. Kolesova DA. [Bacterioses as the initial cause of fungal diseases of fruit trees and their control] Nauchnye trudy GNU SKZNIISiV. 2013; 2: 65-74. Russian.

13. Pasichnyk LA. [Antigenic properties of Pseudomonas syringae pathovars affecting grain crops] Microbiology Journal. 2000; 62(5):18-22. Ukrainian.

14. Pasichnyk LA, Ghvozdjak RI, Kozyrovsjka NO, Kovaljchuk MV, Neghrucjka VV, Khodos $S F$. [Penetration of Pantoea agglomerans into wheat roots] Bulletin of the Odessa National University. 2005; 10(7): 294-299. Ukrainian.

15. Patyka VP, Pasichnyk LA, Bucenko LM. [Bacterial diseases of grain crops and measures of their control.] The Ukrainian farmer's guide. 2013; (1): 202-208. Ukrainian. 
16. Pasichnik LA, Savenko EA, Butsenko LN, Shcherbina TN, Patyka VF. [Pseudomonas syringae - the causative agent of bacterial diseases in weeds] Microbiology Journal. 2013; 75(4): 41-46. Russian.

17. Pasichnik LA, Savenko EA, Butsenko LN, Patyka VF, Kalinichenko AV. [Pseudomonas syringae in wheat agrophytocenosis] Science and World. International Scientific Journal. 2014; 4(8): 52-56. Russian.

18. Patyka VP, Zakharova OM. [Rape diseases and protection] Scientific notes of the Ternopil Pedagogical University named after Volodymyr Hnatiuk. Series: Biology. 2012; 4(53): 15-20. Ukrainian.

19. Patyka VF, Patyka NV. [Modern problems of biodiversity] Fodder and Fodder Production . 2013; 76: 101-109. Russian.

20. Patyka VP, Pasichnyk LA, Bucenko LM. [Bacterial disease of wheat and rice] Taurian Journal of Agricultural Science. 2013; 1: 51-56. Ukrainian.

21. Patyka VP, Pasichnyk LA. [Pathogenic bacteria: fundamental and applied aspects] Bulletin of Uman National University of Horticulture. 2014; 2: 7-11. Ukrainian.

22. Patyka VP, Pasichnyk LA, Dankevych LA, Moroz SM, Bucenko LM, Zhytkevych NV,et al. [Diagnosis of pathogenic bacteria: Guidelines] Metodychni rekomendaciji /za red. akademika NAAN V.P. Patyky. - Kyiv. 2014; 76 p. Ukrainian.

23. Patyka VP, Zakharova OM. [Rape and its phytosanitary properties] Bulletin of Agricultural Science. 2015; 6: 15-19. Ukrainian.

24. Patyka NV, Kruglov YuV, Berdnikov AM, Patyka VF. [The role of Linum usitatissium L. in microbial communities formation in podzolic soil] Microbiology Journal. 2008; 70(1): 59-70. Ukrainian.

25. Petrychenko VF, Kornijchuk OV, Pasichnyk LA, Bucenko LM, Zhytkevych NV, Ghnatjuk TT, Patyka VP. [Bacterial diseases of crops and pesticides] Bulletin of Agricultural Science. 2013; 4: 21-26. Ukrainian.

26. Roslynnyctvo. Tekhnologhiji vyroshhuvannja siljsjkoghospodarsjkykh kuljtur [Lykhochvor VV, Petrychenko VF, Ivashhuk PV, Kornijchuk OV]. - za red. VV Lykhochvora, VF Petrychenka. - 3-je vyd. - Ljviv: NVF «Ukrajinsjki tekhnologhiji». 2010. Ukrainian.

27. Savenko OA, Pasichnyk LA, Patyka VP. [Pathogens of segetal vegetation in wheat agrocenoses] Scientific notes of the Volodymyr Hnatiuk Ternopil Pedagogical University. Series: Biology. 2015; 62(1): 124-132. Ukrainian.

28. Sajko VF. [Agriculture in current conditions] Bulletin of Agricultural Science. 2002; 5: 5-10. Ukrainian.

29. Symochko LJu, Kormosh SM, Patyka VP. [Capsicum annum L. role in the formation of microbial communities in sod-podzolic soils of Transcarpathia] Bulletin of Kharkiv National Agricultural University. Series: Biology. 2011; 2(23): 95-104. Ukrainian.

30. Jakovleva LM, Zakharchenko TM, Shherbyna TM, Patyka VP. [Bacterial diseases of Convolvulus arvensis L. in sowings of Glycine $\max (\mathrm{L}$.) Merr. and their causative agents] Bulletin of Kharkiv National Agricultural University. Series: Biology. 2010; 3(21): 92-98.Ukrainian.

31. Jakovleva LM, Savenko EA, Janeva OD, Pasychnyk LA. [Yeast as the weed pathogens] Microbiology Journal. 2014; 76(5): 26-33. Ukrainian.

32. Brozowska A, Kalinichenko A, Patyka V, Zacharova O. Development of residential areas in harmony with nature // Transformation management of economic at rural areas: 
collective monograph /edited by A Brzozowska, A Kalinichenko. - Poltava, 2015. p. 55-70.

33. Dutta B, Gitaitis RD, Webster TM et al. Distribution and survival of Pseudomonas sp. on Italian ryegrass (Lolium multiflorum) and Curly dock (Rumex crispus), in Georgia. Plant Disease. 2014; 98(5): 660-666.

34. Louws FJ, Fulbright DW, Stephens CT, de Bruijn FJ. Specific genomic fingerprints of phytopathogenic Xanthomonas and Pseudomonas pathovars and strains generated with repetitive sequences and PCR. Appl. Environ. Microbiol. 1994; 60(7): 2286-2295.

35. Louws FJ, Rademaker ILW, de Bruijn FJ. The three DS of PCR-based genomic analysis of phytobacteria: diversity, detection and diseases diagnosis . Ann. Rev. Phytopathol. 1999; 37: 81-125.

36. Olga Zakharova, Antonina Kalinichenko, Lyudmyla Dankevich, Volodymyr Patyka. Rapeseed bacterial diseases and their REP-PCR analysis. Journal of Pure and Applied Microbiology. 2015; 9(Spl. Edn.1): 205-210.

37. Patyka VH, Pasichnyk LA. Phytopathogenic bacteria in the system of modern agriculture. Microbiology Journal. 2014; 76(1): 21-26.

38. Rademaker JL, Hoste B, Louws FJ, Kersters K, Swings J, Vauterin L, Vauterin P, de Bruijn FJ. Comparison of AFLP and rep-PCR genomic fingerprinting with DNA-DNA homology studies: Xanthomonas as a model system. Int. J. Syst. Evol. Microbiol. 2000; 50(2): 665-677.

39. Young JM, Jones DS, Gillings M. Relationships between populations of Pseudomonas syringae pv. persicae determined by restriction fragment analysis. Plant pathology. 1996; 45: 350-357.

40. Welsh $J$, McClelland M. Fingerprinting genomes using PCR with arbitrary primers. Nucl. Acids. Res. 1990; 18(24): 7213-7218.

41. Williams YGK, Kubelik AR, Livar KJ et al. DNA polymorphisms amplified by arbitrary primers are useful as genetic markers. Nucl. Acids. Res. 1990; 18(22): 6531-6535.

Отримано 22.09.2016 